\title{
The Efficacy of The Integrated Child Development Services in Perspective to Nutritional Condition and Growth Development
}

\author{
Jemy Elizabeth Joseph ${ }^{1}$, Shiju Mathew ${ }^{2}$ \\ ${ }^{1}$ Medical Science, JJT University, Jhunjhunu, Rajasthan-333001, India \\ ${ }^{2}$ Department of Medical Lab Technology, College of Applied Medical Sciences, Jazan University \\ Jazan, Kingdom of Saudi Arabia
}

\begin{abstract}
Article Info
ABSTRACT

Article history:

Received Mar 20, 2014

Revised Dec 20, 2014

Accepted Jan 16, 2015

Keyword:

Health

ICDS

Malnutrition

Nutrition

Preschoolers

A survey was conducted to assess the nutritional status of children (0-6 years) among 40 Anganwadisin 4 districts of Kerala State registered under the ICDS scheme. A self- prepared structured interview schedule was used. To get the qualitative information of the study anthropometric measures include height and weight were used for assessing nutritional status of the children. The stepwise analysis of two variables height for age and weight for age was applicable on the basis of Waterlow's and Gomez' classification. To examine the relationship between nutritional status of the child and selected variable that affects nutritional status of children, Chi-square test was employed. Based on Gomez' classification, out of 400 children, only 300 $(75.0 \%)$ of children received supplementary nutrition through ICDS out of which $250(62.5 \%)$ children were normal while $50(12.5 \%)$ were underweight. Based on Waterlow's classification out of 400 children, only $290(72.5 \%)$ of children received supplementary nutrition through ICDS out of these children $200(50 \%)$ were normal while $90(22.5 \%)$ were stunted. It can thus be concluded that majority of children were normal who received supplementary nutrition through ICDS.
\end{abstract}

Copyright (C) 2015 Institute of Advanced Engineering and Science. All rights reserved.

\section{Corresponding Author:}

Jemy Elizabeth Joseph,

Ph.D. Research Scholar in Medical Science,

JJT University,

Jhunjhunu, Rajasthan-333001, India.

Email: jemyshiju@gmail.com

\section{INTRODUCTION}

India has one of the highest percentages of the severe malnourished children's in the world along with Sub-saharan Africa reigon [1]-[3]. Malnutrition is "the syndrome that results from the interaction between poor diets and disease and leads to most of the anthropometric deficits observed among children in the worlds less developed countries" [4]. Integrated Child Development Service Scheme is a unique programme, which encompasses the main components of human resource development, namely - health, nutrition and education. The National Policy for children adopted in 1974 has emphasized the need to accord priority to children, in the country's developmental efforts. The policy statement focuses on preventive and promotive aspects of child health and nutrition for expectant and nursing mothers. It aims to provide adequate services for children both before and after birth and throughout the period of growth to ensure their full physical, mental and social development. There are studies done which shows that there is a positive impact of ICDS on child nutritional status. Singh et al. (1993) and Chiani et al. (1994) have found positive impact of ICDS on child nutritional status. The nations of the world are ranked according to their achievements in fulfillment of child rights and progress for women. A majority of children live in impoverished economic, social and environmental condition, which impedes their physical and mental development. Recognizing the India government has been greatly concerned about safeguarding and 
enhancing the development of children particularly those from the weaker sections of society [5]-[10] Emphasizing on the above significance of positive impact of ICDS on children and their nutritional status, the present paper was conducted to evaluate the nutritional status of children aged between 0-3 years registered in government sponsored maternal and child care Anganwadicenters in India.

\section{RESEARCH METHOD}

A survey- based study was conducted in the month of February,2013 to January, 2014, among 40 Anganwadisin 4 districts of Kerala State i.e., Thiruvananthapuram, Kollam, Pathanamthitta and Kottayam registered under the ICDS scheme. For the study the permission has been taken from the government official at Directorate of Social Welfare, Thiruvanthapuram (Govt. of Kerala). A self prepared structured interview schedule was prepared and pretested in the field. In the present study anthropometric measurements (height and weight) were used for assessing nutritional status of the children. Children were examined in the Anganwadiswhere their heights and weights were taken. A complete assessment of nutritional status includes the collection of anthropometric data. A standard measuring tape was used to measure height. Children were weighed using a standardized Salter's scale to the nearest 100 grams when attending an Anganwadi. Total a number of 400 children were taken for the study as sample and for all of them the supplementary food was provided. Weight for age and height for age were calculated and children were classified into different grades of malnutrition according to Gomez's and Waterlow's classification [11]. Data of 400 children were analyzed using the Statistical Package for Social Sciences (SPSS) version 20.0.

\begin{tabular}{cc}
\hline Classification by Gomez et al. & \\
\hline Normal & $>90 \%$ of standard weight for age \\
Grade I & $89 \%-75 \%$ of standard weight for age \\
Grade II & $74 \%-60 \%$ of standard weight for age \\
Grade III & $<60 \%$ of standard weight for age \\
\hline Classification by Waterlow & $>95 \%$ of height for age \\
Normal & $87.5 \%-95 \%$ of height for age \\
Mildly impaired & $80 \%-87.5 \%$ of height for age \\
Moderately impaired & $<80 \%$ of height for age \\
Severely impaired &
\end{tabular}

\section{RESULTS AND ANALYSIS}

\subsection{Supplementary Nutrition}

Malnutrition is clearly linked to inappropriate feeding practices rather than just to food availability or household food security. ICDS/Anganwadiscenters are supposed to provide supplementary feeding and inculcate good feeding practices among mothers. Supplementary feeding should be introduced at around 6 months of age in addition to continued breastfeeding upto two years of age. According to ICDS norms, identified severely malnourished children, those placed in Grade III and Grade IV, should be given special supplementary feeding which may be therapeutic in nature, or just double rations, and should also be referred to medical services. However, since the nutritional status of the ICDS children was rarely recorded or categorized in different grades as per the growth chart, no variation in the quantity of food given to these children was observed. All the children were provided with the same quantity of food. Table 1 data shows that only $75.0 \%$ of children had received the supplementary nutrition through ICDS and $25.0 \%$ of children did not receive supplementary nutrition. Williams (1988) conducted a study which revealed that ICDS provided nutrition supplements consisting of 300 calories and $10 \mathrm{~g}$ of proteins for all 60-72 month old children. The similar work has been reported by Ali and Jahan (2012) and Swaminathan (1990) on the impact of ICDS programme; found that the mothers of ICDS areas were better informed of the care during pre-natal period, importance of supplementary feeding, growth services to children and to improve the capability of mothers to meet the help and nutritional needs of their children through proper nutrition education [12]-[16].

Table 1. Percentage distribution of children who received/ did not receive supplementary nutrition through ICDS $(\mathrm{N}=300)$

\begin{tabular}{lcc}
\hline \multicolumn{1}{c}{ Supplementary nutrition through ICDS } & Number & Percentage \\
\hline Received & 300 & 75.0 \\
Did not receive & 100 & 25.0 \\
Total & 400 & 100.0 \\
\hline
\end{tabular}

IJPHS Vol. 4, No. 1, March 2015 : 17 - 20 
Table 2 shows that based on Gomez' classification, out of $25.0 \%$ children who did not receive supplementary nutrition, majority $15.0 \%$ of their children was underweight. On the other hand, out of $75.0 \%$ children, who received supplementary nutrition majority $62.5 \%$ of children, were having normal weight for age. To examine the relationship between nutritional status (weight) of children and those who received supplementary nutrition, null hypothesis was formulated, that is, children who received supplementary nutrition had no effect on nutritional status (weight). To examine the hypothesis chi-square test was used. Calculated value of $\chi^{2}$ was 46.7 and table value of $\chi^{2}$ at $5 \%$ level of significance and 1 degree of freedom was 3.5. Calculated value was greater than table value. So null hypothesis was rejected, that is, children, who received supplementary nutrition, had better nutritional status (weight).

Table 2. Percentage distribution of health status (weight) of children according to Children who receive/ did not receive supplementary nutrition through ICDS (Gomez' classification weight for age) $\mathrm{N}=400$

\begin{tabular}{|c|c|c|c|c|c|c|}
\hline \multirow{3}{*}{$\begin{array}{l}\text { Supplementary nutrition Health } \\
\text { status of childrenthrough ICDS }\end{array}$} & \multicolumn{6}{|c|}{ Health status of children } \\
\hline & \multicolumn{2}{|c|}{ Normal } & \multicolumn{2}{|c|}{ Underweight } & \multicolumn{2}{|c|}{ Total } \\
\hline & No. & $\%$ & No. & $\%$ & No. & $\%$ \\
\hline Received & 250 & 62.5 & 50 & 12.5 & 300 & 75.0 \\
\hline Did not receive & 40 & 10.0 & 60 & 15.0 & 100 & 25.0 \\
\hline Total & 290 & 72.5 & 110 & 27.5 & 400 & 100.0 \\
\hline
\end{tabular}

$\chi^{2}=46.7$ at d.f $1 ; \mathrm{P}<0.05$

Table 3. Percentage distribution of health status (weight) of children according to Children who receive/ did not receive supplementary nutrition through ICDS (Waterflow's classification weight for age) $\mathrm{N}=400$

\begin{tabular}{lcccccc}
\hline Supplementary nutrition & \multicolumn{6}{c}{ Health status of children } \\
\cline { 2 - 7 } $\begin{array}{c}\text { Health status of children } \\
\text { through ICDS }\end{array}$ & No. & $\%$ & No. & $\%$ & No. & $\%$ \\
\cline { 2 - 7 } & 200 & 50 & 90 & 22.5 & 290 & 72.5 \\
\hline Received & 80 & 20 & 30 & 7.5 & 110 & 27.5 \\
Did not receive & 280 & 70.0 & 120 & 30.0 & 400 & 100.0 \\
Total & & & & &
\end{tabular}

Table 3 indicates that based on Waterlow's classification out of $27.5 \%$ children who did not receive supplementary nutrition, $7.5 \%$ children were stunted. Out of $72.5 \%$ children who received supplementary nutrition, majority $50 \%$ of the children were of normal height for their age. To examine the relationship between nutritional status (height) of children and supplementary nutrition receive by children, null hypothesis was formulated, that is, supplementary nutrition received by children has no effect on their nutritional status (height). For testing the hypothesis chi-square test was use. Calculated value of $\chi^{2}$ was 2.01 and table value of $\chi^{2}$ at $5 \%$ level of significance was 3.21. Calculated value was less than table value so null hypothesis was accepted, that is, supplementary nutrition receive by children has no effect on their nutritional status (height).

\section{DISCUSSION}

Adequate food and good feeding practices are essential for the normal growth of a young child. Studies conducted by Alhajiet al. (2002) show that 150 million (26.6\%) were underweight, while 182 million $(32.5 \%)$ were stunted all over the world. More than half of the world's undernourished people live in India. Mishra et al. (1999) in their study found that about 54\% children were underweight, 52\% were stunted, while $17 \%$ were wasted. The Study done by Tamannaet al. (2010) shows that the nutritional status of children did not vary from normal to $3^{\text {rd }}$ degree malnourishment. Nearly $45.8 \%$ were normal, $1.8 \%$ were over nourished and $2.2 \%$ were $3^{\text {rd }}$ degree malnourished. So, we need to give highest priority to child health and nutrition if we hope for a brighter future of our country. The height for age index shows about $229(76.4 \%)$ of children received supplementary nutrition through ICDS. Out of these children 148 (49.4\%) were normal while 81 $(27 \%)$ were stunted. The extent of severe under-nutrition was higher in Uttar Pradesh and Rajasthan while severe under-nutrition of a chronic nature was higher in Orissa. Further operational research is needed to find out the reasons for the substitution of the supplementary food for breakfast or lunch, the exact caloric content of Anganwadifood given to the children. Garget al. (1997) in Ghaziabad, Bhandariet al. (1993) in Rajasthan, found that prevalence of malnutrition in children below the age of five years was higher in spite of the fact that these population was being served by ICDS [17]. A limitation of this study was not accounting for the 
registered Anganwadischildren who did not attend the Anganwadiscenters, but for whom supplementary food was provided. This could have opened another dimension for the study [18]-[21].

\section{CONCLUSION}

To prevent or minimize the problem of malnutrition, various nutrition intervention programmes have been introduced, from time to time, in India. Although the ICDS program has been successful in improving the nutritional status of children ( $0-6$ years), further improvements can be made in the functioning of the program. Changes need to be made in the understanding and utilization of the services. The study shows the high extent of undernourishment and less than satisfactory performance of ICDS, about 250 (62.5\%) children was normal while only $50(12.5 \%)$ were underweight who had receive supplementary nutrition through ICDS.

\section{ACKNOWLEDGEMENT}

The author thank the children and their mothers who have willingly participated in this study and a special thanks to the Directorate of Social Welfare, Government of Kerala, Kerala (India)for granting the permission for conducting the study.

\section{REFERENCES}

[1] Alhaji M., Allen S.,"Paediatric review: Management of severe malnutrition-time for a change?”,Africa Health, vol. 24, pp. 21-23, 2002.

[2] Alim F., Jahan F., "Assessment of Nutritional Status of Rural Anganwadi Children of Aligarh under the ICDS and Rural Health",Stud Home Com Sci, vol/issue: 6(2), pp. 95-98, 2012.

[3] Arimond M.,Ruel T.,"Assessing care:Progress towards the measurement of selected child care and feeding practices, and implications for programs", Washington, DC, USA: Food and Nutrition Technical Assistance Project, Academy for Educational Development, 2002.

[4] Bhandari B., Gupta AP., Mandowara SL., Sahara P., Singhal M.,"Decadal changes in nutritional and immunization status of ICDS beneficiaries",Indian J Maternal and Child Health, vol/issue: 4(1), pp. 9-10, 1993.

[5] Census of India, 2001. From <http://censusindia.govt.in/Census_Data_2001/India at glance/broad.aspex> (Retrieved on 17 July 2011).

[6] Chiani N., Sharma P., Meena N., Sharma U.,"Pattern of vitamin deficiency among the malnourished pre- school children in ICDS block of Jaipur city",Indian J.Maternal and Child Health, vol/issue: 5(4), pp. 109-111, 1994.

[7] Dasgupta M., Gragnolati M., Ivashenko O.,"Improving Child Nutrition? The Integrated Child Development Services in India?”,Development and Change,vol/issue: 36(4), pp. 613-640, 2005.

[8] Deutsch FM., Lussier JB., Servis LJ."'Husbands at home: Predictors of paternal participationin childcare and housework", "Journal of Personality and Social Psychology,vol/issue: 1(6), pp. 1154-1166, 1993.

[9] Engle P., "Care and Child Nutrition",Paper for the International Conference on Nutrition. UNICEF, New York,Archives of Pediatrics and Adolescent Medicine,vol/issue: 161(8), pp. 730-739, 1992.

[10] Garg SK., Singh JV., Bhatnagar H.,"Nutritional status of children (1-6 year) in slum of Ghaziabad city",Ind J Community Medicine, vol/issue: 22(2), pp. 70-73, 1997.

[11] Kandpal E., McNamara PE.,"Persistent Child Malnutrition in India: Evidence from the National Family Health Survey (2005-06)",Economic and Political Weekly,vol/issue: 6(2), pp. 34-43, 2008.

[12] Swaminathan M.,"Principles of Nutrition and Dietetics",Bangalore: Bangalore Printing and Publishing Co. Ltd, 1990.

[13] Tamanna N., Shafia K, Marufa S., Nurul I., Ohtani K.,"Determinates of malnutrition among children under 2 years of age", Pakistan J Nutr, vol/issue: 9(1), pp. 27-34, 2010.

[14] WHO,"Physical Status: The Use and Interpretation of Anthropometry. Report of a WHO Expert Committee",WHO Technical Report Series 854. WHO, Geneva, 1995.

[15] Wilford R., Golden K., Walker DG., "Cost-effectiveness of community-based management of acute malnutrition in Malawi”,Health policy and planning,vol/issue: 27(2), pp. 127-137, 2012.

[16] Williams RS.,"Basic Nutrition and Diet Therapy”,9 $9^{\text {th }}$ Edition. St. Louis: Mosby Year Book, Inc, 1988.

[17] Khanna K.,"A Text Book of Nutrition and Dietetics”, New Delhi: Phoenix Publishing House Pvt. Ltd, 1997.

[18] Mishra VK.,Lahiri S., Luther NY.,"Child Nutrition in India: National Family Health Survey Subject Reports”, Mumbai: International Institute of Population Sciences, 1999.

[19] National Statistics Office (NSO),"Malawi demographic and health survey 2010”,Zomba, Malawi: Malawi National Statistics Office (NSO), 2011.

[20] Ruel MT.,“Operationalizing dietary diversity: a review of measurement issues and research priorities”,The Journal of Nutrition,vol/issue: 133(11), pp. 3911-3926, 2003.

[21] Singh SP., Reddy DCS., Mohapatra SC., Gaur SD.,"Study of infant and childhood mortality in an ICDS block of eastern UP”,Indian J Public Health, vol/issue: 37(2), pp. 61-65, 1993. 